\title{
Cost-benefit analysis of trading strategies in the stock index futures market
}

\author{
Xiong Xiong ${ }^{1}$, Yian Cui ${ }^{2 *}$, Xiaocong Yan ${ }^{1}$, Jun Liu ${ }^{1}$ and Shaoyi $\mathrm{He}^{3}$
}

\author{
* Correspondence: yacui@szse.cn \\ ${ }^{2}$ Research Institute, Shenzhen Stock \\ Exchange, Shenzhen 518038, China \\ Full list of author information is \\ available at the end of the article
}

\begin{abstract}
With the introduction of many derivatives into the capital market, including stock index futures, the trading strategies in financial markets have been gradually enriched. However, there is still no theoretical model that can determine whether these strategies are effective, what the risks are, and how costly the strategies are. We built an agent-based cross-market platform that includes five stocks and one stock index future, and constructed an evaluation system for stock index futures trading strategies. The evaluation system includes four dimensions: effectiveness, risk, occupation of capital, and impact cost. The results show that the informed strategy performs well in all aspects. The risk of the technical strategy is relatively higher than that of the other strategies. Moreover, occupation of capital and impact cost are both higher for the arbitrage strategy. Finally, the wealth of noise traders is almost lost.

Keywords: Trading strategy, Stock index futures, Agent-based model, Cost-benefit analysis
\end{abstract}

\section{Introduction}

China Shanghai-Shenzhen 300 Stock Index Futures (CSI 300 Stock Index Futures) contracts began trading in April 2010. The trading strategies in financial markets have been gradually enriched with the introduction of stock index futures. In the capital market, trading strategies can be generally divided into informed, technical, and noise strategies. In addition, stock index futures have unique trading strategies, such as hedging and arbitrage. For investors, different trading strategies produce different benefits and costs. At the same time, the behavior of investors also affects the market index and overall market operation, which in turn influence the benefits, costs, and risks associated with trading strategies. Therefore, analyzing the different trading strategies in the stock index futures market is of great significance.

Following Xu et al. (2014), we built an agent-based cross-market model that includes five stocks and one stock index future. Based on this artificial stock market, we constructed a four-dimensional evaluation system for trading strategies in the stock index futures market. Then, we simulated a series of experiments to analyze the costs, benefits, and risks of different trading strategies. The experimental results show that the

(c) The Author(s). 2020 Open Access This article is licensed under a Creative Commons Attribution 4.0 International License, which permits use, sharing, adaptation, distribution and reproduction in any medium or format, as long as you give appropriate credit to the original author(s) and the source, provide a link to the Creative Commons licence, and indicate if changes were made. The images or other third party material in this article are included in the article's Creative Commons licence, unless indicated otherwise in a credit line to the material. If material is not included in the article's Creative Commons licence and your intended use is not permitted by statutory regulation or exceeds the permitted use, you will need to obtain permission directly from the copyright holder. To view a copy of this licence, visit http://creativecommons.org/licenses/by/4.0/. 
informed trading strategy performs well in terms of effectiveness, risk, the occupation of capital, and impact cost, indicating that the analysis of market information is very important. The noise trading strategy suffers heavy losses. The technical trading strategy performs well in the areas of effectiveness, the occupation of capital, and impact cost but has a relatively larger risk. Although the returns and risks of arbitrage trading are reasonable, this strategy requires a lot of money. Further, because of the larger capital occupation and impact costs, investors using this strategy must focus on market changes.

This article comprehensively evaluates stock index futures trading strategies, provides suggestions for investor trading behaviors, provides a theoretical foundation for the development and innovation of stock index futures markets, and provides experimental evidence for the stability and development of the stock index futures market. The rest of the article is organized as follows. Literature review section introduces the related literature. Agent-based cross-market model section describes the model while Experiment design and results analysis section presents the experiments design and analyzes the results. Conclusion and discussion section provides the conclusion and discussion.

\section{Literature review}

As financial derivatives, stock index futures have many functions, such as hedging, asset allocation, and price discovery. Stock index futures, which have unique advantages and can be traded in many ways, play an important role in the capital market. Therefore, since its launch in the US in 1982, the stock index futures market has attracted widespread attention from researchers (Chang et al. 1999; Sarkar and Tripathy 2002; Antoniou et al. 2005; Bohl et al. 2011; Hua and Liu 2010; Yang and Wan 2011; Tong 2011; Wei et al. 2014).

Different from the stock market, stock index futures products are very instrumental; thus, trading strategies for stock index futures began to attract scholarly attention. Using a series of time series models, Brooks et al. (Brooks et al. 2001) examined the lead-lag relationship between the FTSE 100 index and index futures prices; they found that lagged changes in the futures price could help predict changes in the spot price. Laws and Thompson (2005) studied the efficiency of hedging stock portfolios using futures stocks during the period January 1995 to December 2001. They found that the exponential weighted moving average (EWMA) method of estimation provided the best estimate of the optimal hedge and that the FTSE 250 was the best hedging tool for these portfolios. In an empirical study, Lee and Tsang (2011) found that, in general, simultaneous hedging with both American depositary receipts (ADRs) and index futures would bring benefits, thus enhancing the performance of hedging transactions.

In terms of research methods, studies of stock index futures mainly use quantitative methods. There are some gaps between the results obtained using quantitative methods and the real market. As a new method that can sufficiently reflect the real market, the agent-based model is used in this study. The agent-based model views the financial market as a complex adaptive system that contains a plurality of heterogeneous agents. Based on bottom-up microscopic modeling methods and advanced computer simulation technologies, an agent-based model can deeply reveal the general laws of the financial market-an area that has garnered considerable research attention (Battiston et al. 
2016; Chen and Venkatachalam 2017; Lussange et al. 2018; Iori and Porter 2018; Cui et al. 2020; Zhao et al. 2020).

Using the agent-based approach, Schmitt and Westerhoff (2014) were the first to propose a cross-market financial agent-based model. Jacob Leal et al. (2016), meanwhile, were the first to propose a high-frequency financial agent-based model. Chen and Liao (2005) examined possible explanations for the presence of a causal relationship between stock returns and trading volume. Kobayashi and Hashimoto (2007) considered the influence of circuit breakers on the stock market using an agent-based artificial market simulator called "U-Mart". They found that circuit breakers play an important role in the control of price fluctuations and the stabilization of the settlement system. On the basis of imitation between agent and market sentiment signals on an experimental computing platform, Chen et al. (2010) concluded that stock price bubbles or crashes are caused by synergy herding behavior; they found a strong correlation between herd behavior and earnings volatility. Using an agent-based model, Li et al. (2012) focused on the effects on market liquidity of different tick-size levels; they found that decreasing the tick size could significantly improve market liquidity. Wu et al. (2013) constructed a double-auction continuous artificial stock market platform to investigate effects of short selling. Using an agent-based cross-market model, Xiong et al. (2017) examined the effect on the quality of the stock index futures market when a $\mathrm{T}+1$ trading system in the spot market turned into a $\mathrm{T}+0$ trading system. Arthur et al. (1996), meanwhile, used agent-based modeling to study the capital market and constructed an artificial stock market (ASM). Finally, the book Handbook of Computational Economics II by Tesfatsion (2006) signaled the maturation of the agent-based model.

From the above, we can see that research on stock index futures and trading strategies is very common and that agent-based methods are relatively mature. However, in light of the difficulty of evaluating trading strategies, no previous studies have used agent-based methods to establish an evaluation system for common trading strategies in the stock index futures market.

\section{Agent-based cross-market model}

This study is based on the artificial agent-based cross-market model designed by Xu et al (2014) The main characteristics of this model are consistent with the main features of the Chinese stock market and the CSI 300 stock index futures market. The present model contains a stock market that includes five stocks. A stock index was formed on the basis of the stock market, and an index futures market was formed. There are three types of investors in the stock market and in the stock index futures market: informed traders, technology traders, and noise traders. The model also includes a cross-market arbitrage trader who trades in both the stock market and the stock index futures market. In this model, the investor's investment demands are endogenously determined and are constrained by investor wealth, investor risk management level, and trading mechanism.

\section{Assets}

In the artificial market model built in this study, there are five stocks and one stock index future. The evolution of the stock's public value is as follows: 


$$
v_{i, t+1}^{*}=\left(1+\phi_{i}+\sigma_{i, \varepsilon} \varepsilon_{t+1}\right) v_{i, t}^{*}
$$

We assume $\phi_{i}=0, \varepsilon_{t} \in N(0,1) . \sigma_{i, \varepsilon}>0$ represents the standard deviation in this diffusion process.

The model contains five stocks as basic assets. These five stocks represent five different industries and therefore have different initial prices, different capital, and different volatility. The initial prices of the five stocks are 10, 20, 30, 40, and 50. The corresponding share capitals (in 100 million) are 50, 40, 60, 30, and 50, respectively. The corresponding standard deviations of disturbance are 0.0007, 0.0007, 0.0003, 0.0003, and 0.0005 , respectively.

Based on the five stocks in the market, the base point is 3000 points. Accordingly, we obtained a capitalization-weighted index as follows ${ }^{1}$ :

$$
I_{i}=\frac{M_{t}}{M_{0}} \times 3000=\frac{\sum p_{i, t} S_{i}}{M_{0}} \times 3000
$$

where $M_{t}$ is the sum of current stock price $p_{i, t}$ multiplied by share capital $S_{i}$, and $M_{0}$ is the base market value.

\section{Design of the market}

We designed a trading system that is consistent with the Chinese market scenario. The specific trading mechanism in the model is designed as follows:

(1) Both the stock index futures market and the stock market adopt a continuous double-auction trading mechanism, consistent with the real mechanism in the Chinese stock market. Limit orders have a life cycle, and unexecuted limit orders are cleared at the end of the day.

(2) To ensure consistency in the trading mechanism between the stock index futures market and the stock market, both adopt the $\mathrm{T}+0$ trading mechanism. ${ }^{2}$

(3) Each simulation period $t$ in the model represents five seconds in the real market.

(4) The stock market is not allowed to sell short while the futures market is allowed to do so.

(5) The stock index futures market adopts the method of margin trading. After the daily closing, the balance of the margin account is liquidated. If the investor's assets are lower than the minimum margin requirement, they will be forcibly closed.

(6) The trading price of the market is the average price of multiple transactions at time $t$. If there are no transactions within time $t$, then the price continues the market price at time $t-1$.

(7) The tick size in the stock market and stock index futures markets is set to 0.01 yuan.

(8) There is no transaction cost in the stock market and the stock index futures market.

\footnotetext{
${ }^{1}$ We revised the stock index calculation method used in Xu et al. (2014).

${ }^{2}$ For research on the impact of inconsistent trading mechanisms on the spot-futures cross-market, see Ref. (Xiong et al. 2017).
} 
(9) If the total wealth of the investor is lower than a certain amount, the investor is bankrupt, and another investor of the same type will reenter the market.

\section{Investor structure and investor behavior}

The model includes seven types of investors. The stock market has three types of investors: informed investors, technical investors, and noise investors. The stock index futures market includes three types of investors: informed investors, technical investors, and noise investors. Arbitrage investors, meanwhile, trade simultaneously in both the stock index futures market and the stock market. When investors enter the market, they randomly select an asset. During the subsequent transaction, they will only trade the selected asset and will not trade other assets. ${ }^{3}$

Owing to the lack of short-selling tools in the Chinese stock market, arbitrage investors in this model only allow positive arbitrage. Positive arbitrage can only sell stock index futures and buy stocks in the arbitrage-free zone; reverse operations are not allowed.

\section{Trader expectation of asset price}

Here, we discuss the process of price forecasting by informed investors, technical investors, and noise investors.

(1) An informed trader in the stock market accurately understands the public value of the stock; the price forecast for the stock is as follows:

$$
\hat{p}_{t+\tau \_s t o c k}^{i}=v_{t+\tau}
$$

Informed traders in the stock index futures market cannot directly know the public value of stock index futures; however, they can calculate the theoretical value of the stock index futures as follows ${ }^{4}$ :

$$
\hat{p}_{t+\tau \text {-futures }}^{i}=\hat{I}_{t+\tau}(1+r)^{T-d+1}=\frac{\sum v_{i, t+\tau} S_{i}}{M_{0}} \times 3000 \times(1+r)^{T-d+1}
$$

where $I_{t}$ is the index at time $t, T$ means maturity, and $d$ is the number of days the stock index future has been listed. $r$ is the daily risk-free rate, set to 4\%/360 in this study.

(2) Technical traders cannot know the future public value $v_{t+\tau}$; however, they know the current public value $v_{t}$. They obtain their expected prices by mixing three sources: current public value $v_{t}$, the average transaction price of the last $\tau$-period $\bar{p}_{\tau}$, and the current mid-point of the bid and ask prices $p_{m}$. The variables $a_{i}, b_{i}$, and $c_{i}$, which represent the weights, are randomly chosen from $[0,1]$. The forecast price of the technical investor for the asset is as follows:

\footnotetext{
${ }^{3}$ Therefore, the model in this study is essentially a single-asset model that does not consider the asset allocation of investors for multiple assets.

${ }^{4}$ We revised the price forecasting method used in Xu et al. (2014).
} 


$$
\hat{p}_{t+\tau}^{i}=\frac{\left(a^{i} v_{t}+b^{i} \bar{p}_{\tau}+c^{i} p_{m}\right)}{a^{i}+b^{i}+c^{i}}
$$

(3) According to the actual situation of the order book, the noise trader chooses from within the five price levels; $\operatorname{rand}_{t}^{i}$ is a random function whose output follows a uniform distribution from $[0,1]$, and the forecast price of the noise trader is as follows:

$$
\hat{p}_{t+\tau}^{i}=b i d_{5}+\operatorname{rand}_{t}^{i} \times\left(a s k_{5}-b i d_{5}\right)
$$

\section{Order submission rules}

The investor's order type was determined according to the actual situation of the order book and was compared with the first-order buying (or selling) price. If the transaction can be completed in real time, the order is considered a market order; otherwise, it is considered a limit order. Regarding arbitrage investors, they pursue real-time trading and therefore only submit market orders.

In this model, the investor's optimal position depends on utility function. Following Chiarella et al. (2009), investors make decisions by maximizing the constant absolute risk-aversion (CARA) utility function. Investors' optimal positions are as follows:

$$
\pi^{i}(p)=\frac{\ln \left(\hat{p}_{t+\tau}^{i} / p\right)}{\alpha^{i} V_{t}^{i} p}
$$

where $\alpha^{i}$ is the absolute risk-averse coefficient, $V_{t}^{i}$ is the variance of the expected return, $\hat{p}_{t+\tau}^{i}$ is the forecast price at period $t+\tau^{i}$, and $p$ is the order submission price. If demand quantity $\pi^{i}(p)$ is larger than the investor's current position, the investor decides to buy. If demand quantity $\pi^{i}(p)$ is smaller than the investor's current position, the investor decides to sell. $V_{t}^{i}$ is estimated as follows:

$$
\begin{aligned}
V_{t}^{i} & =\frac{\sum_{j=1}^{\tau}\left(r_{t-j}-\bar{r}_{t}^{i}\right)^{2}}{\tau^{i}} \\
\bar{r}_{t}^{i} & =\frac{\sum_{j=1}^{\tau} r_{t-j}}{\tau^{i}}=\frac{\sum_{j=1}^{\tau} \ln \left(p_{t-j} / p_{t-j-1}\right)}{\tau^{i}}
\end{aligned}
$$

\section{Experiment design and results analysis}

This study mainly evaluates trading strategies for stock index futures based on costbenefit analysis. High-frequency data were obtained through simulation experiments by modeling the stock market and the stock index futures market. This study attempts to establish an evaluation framework for trading strategies-including wealth growth rate, volatility of wealth growth rate, capital occupancy, and impact cost-to explore the effectiveness, risks, and costs of these trading strategies. 


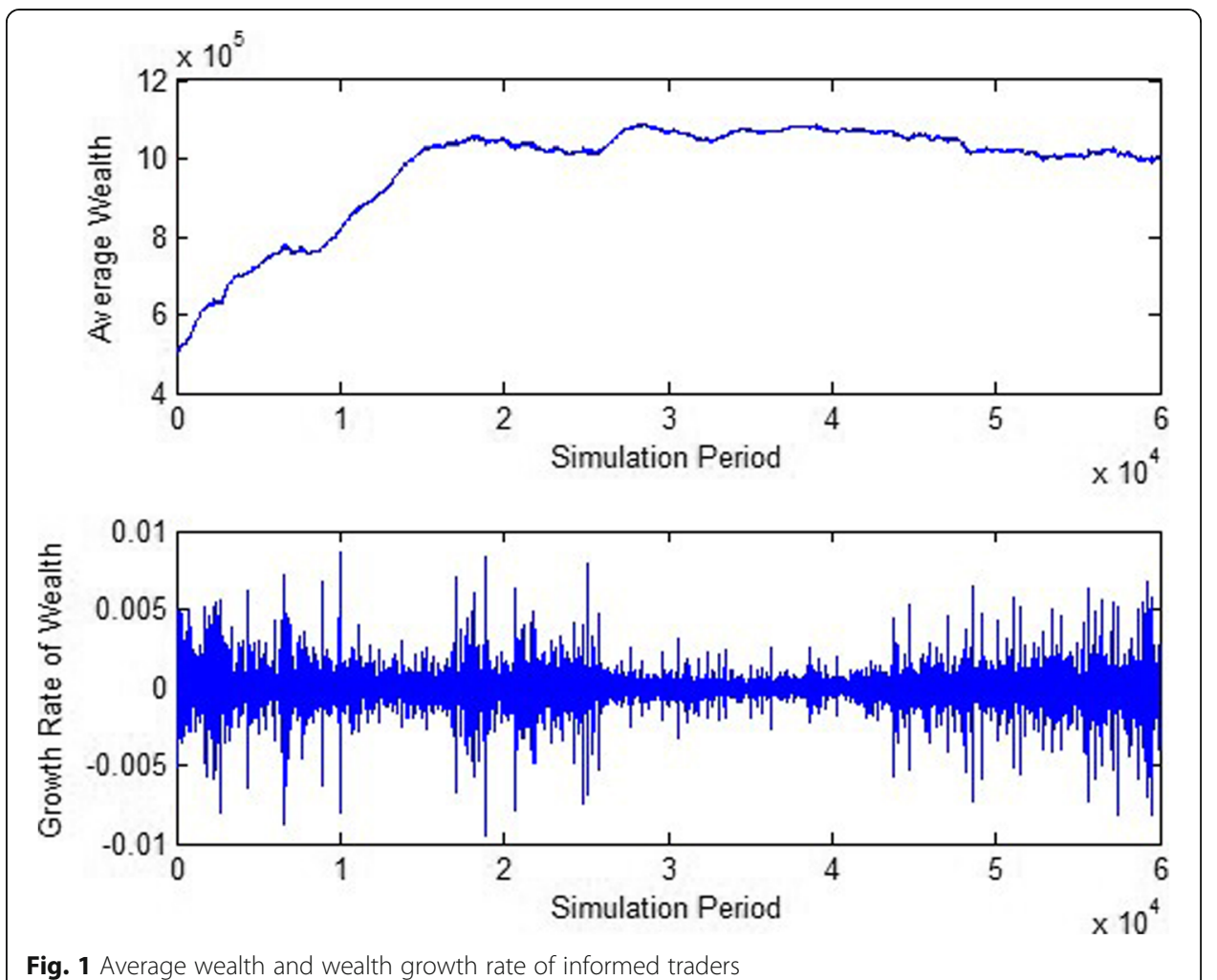

\section{Experimental parameter settings}

Since China's stock index futures market adopts a daily mark-to-market system, we used the day for the frequency of data analysis, except for the time series chart (Figs. 1, 2, 3 and 4) showing high-frequency data. Each experiment was run for 21 days, and the data after the strategy warm-up were used for the analysis. ${ }^{5}$ Each group of experiments in the study was carried out 30 times to ensure that the experimental results were statistically significant. At the same time, the important experimental results were analyzed using ANOVA.

To ensure there were enough arbitrage opportunities in the market, we set the number of arbitrage investors to be smaller than that of other types of investors. At the same time, since arbitrageurs need to trade in both markets, we set arbitrageurs to have more initial wealth. The stock index futures contract multiplier was set to 300 , and the margin ratio was set to $12 \%$. Table 1 shows the detailed parameters.

\section{Results analysis}

High-frequency data $(5 \mathrm{~s})$ for four types investors in the stock index futures market are obtained. The figures below display the investors' average wealth and wealth growth rate.

\footnotetext{
${ }^{5}$ Since the investor strategy contains technical strategies, the technical strategy needs to review the historical price series; hence, data are needed for the strategy warm-up. Regarding the length of the warm-up, different market models and different strategies require different lengths of time, which is generally determined by observing the price series trend in the experiment. In this study, after five days ( $2882 * 5$ periods) of simulation, the stock price series performance is stable; thus, the warm-up time is set to five days.
} 

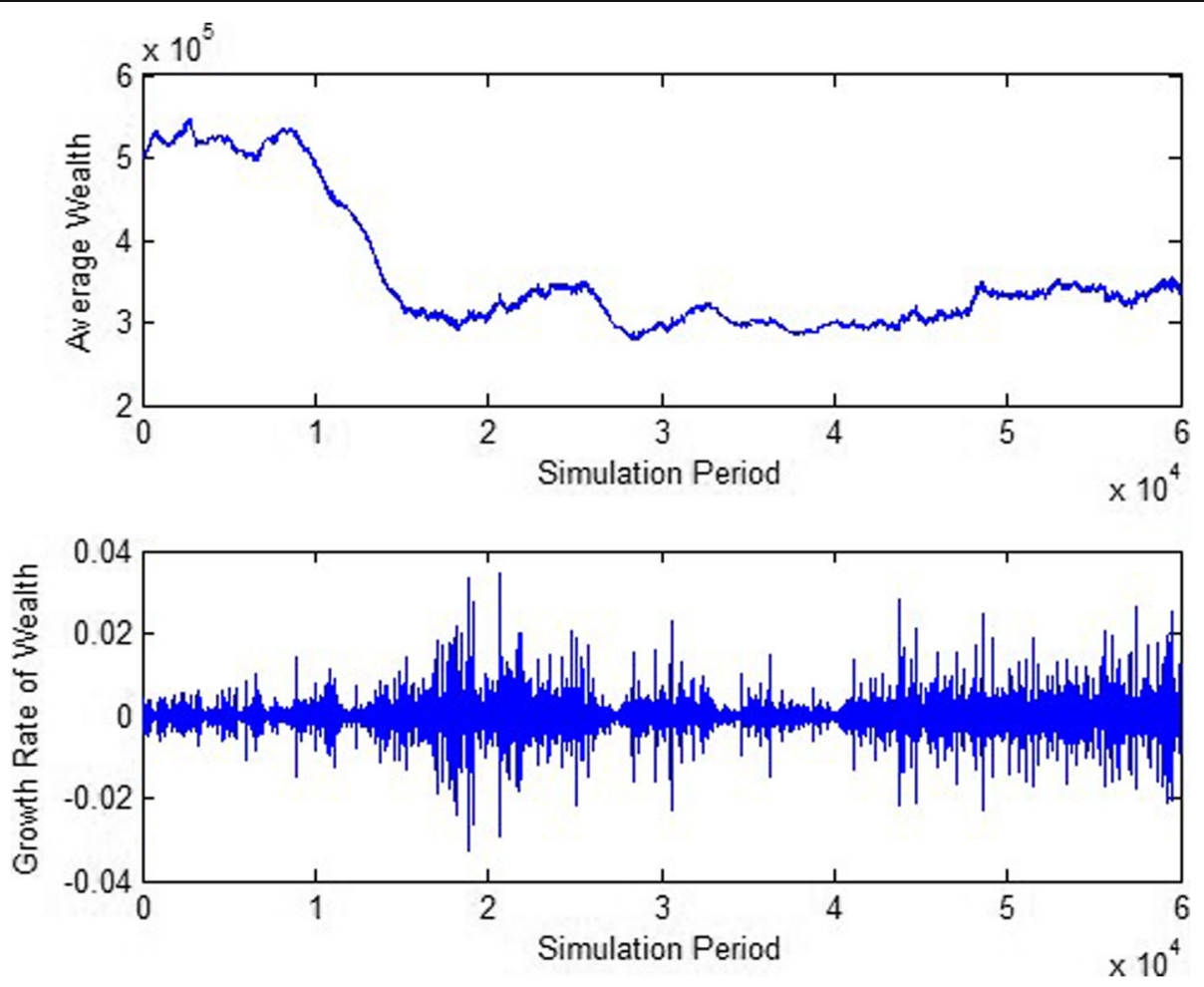

Fig. 2 Average wealth and wealth growth rate of technical traders

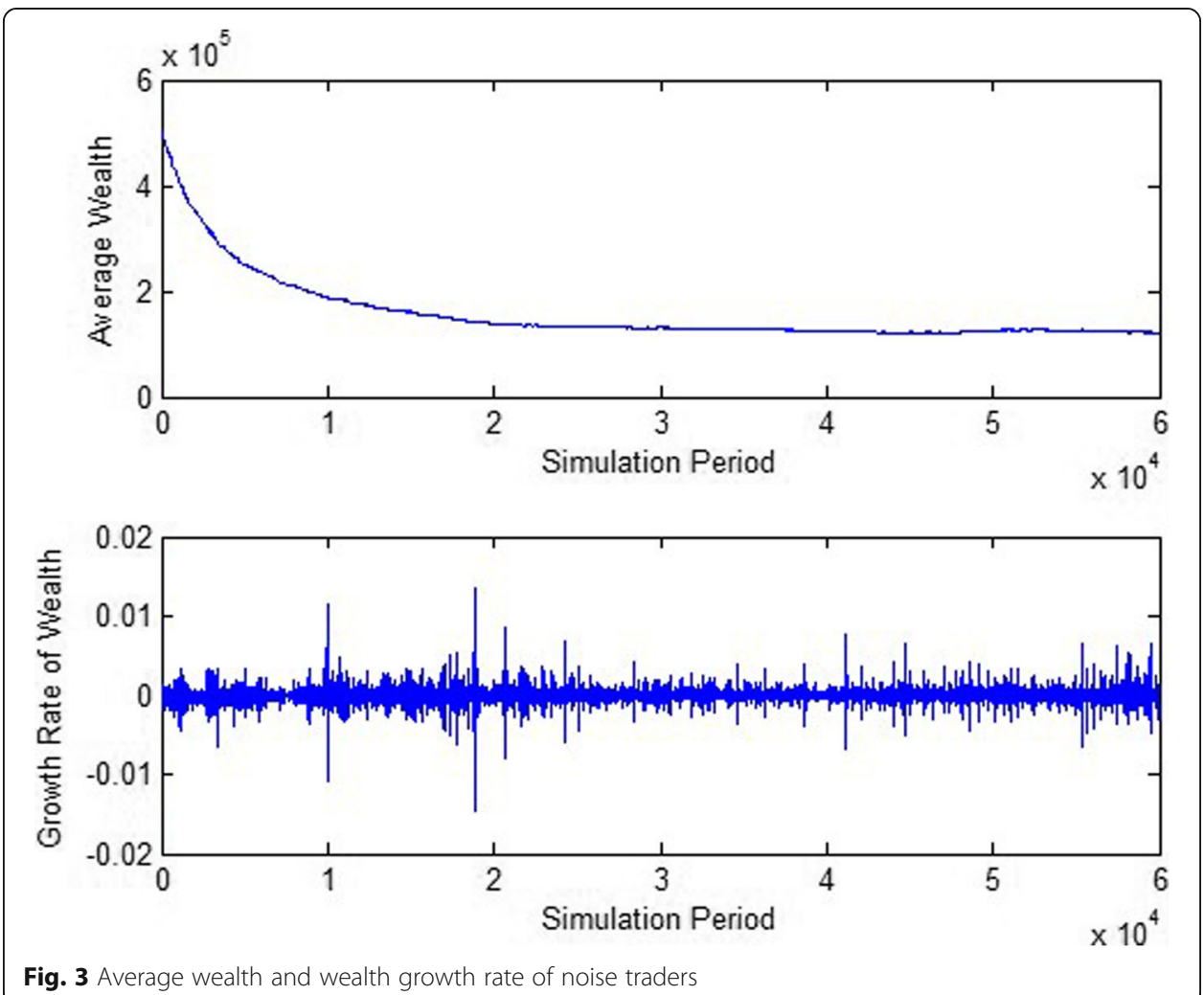

Fig. 3 Average wealth and wealth growth rate of noise traders 


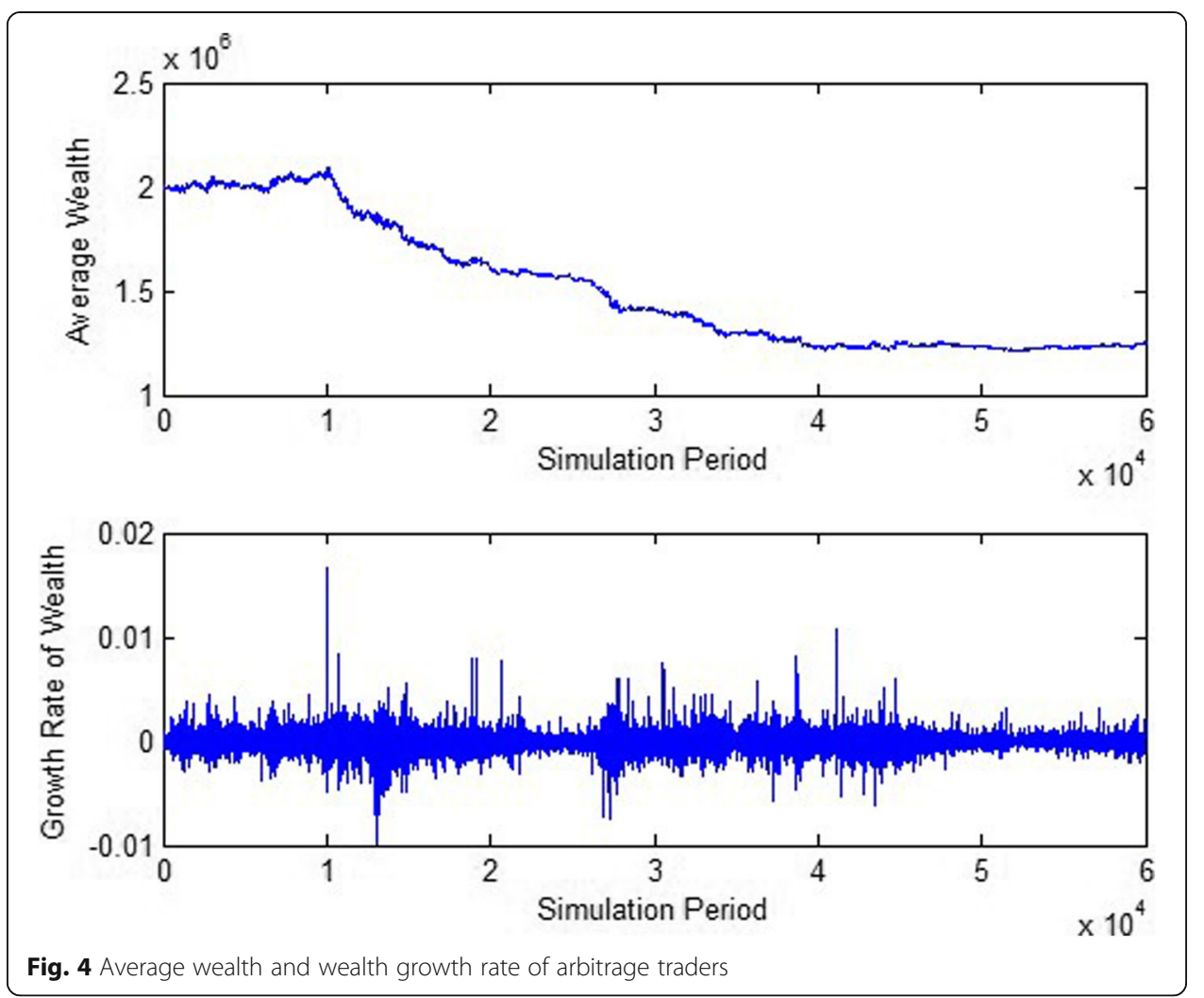

Intuitively, only the wealth of informed traders increases. Other investors are subject to wealth losses. Earnings from technical trading strategies tend to be more volatile, and earnings volatility is similar among the other three types trading strategies.

The evaluation of a trading strategy involves the costs, benefits, and risks. A strategy is considered a good strategy if it has higher earnings, lower costs, and lower risks.

Table 1 Experimental parameter settings

\begin{tabular}{ll}
\hline Experimental parameter & Setting \\
\hline Investor number & \\
Informed trader & 100 \\
Technical trader & 100 \\
Noise trader & 100 \\
Arbitrage trader & 30 \\
Investor wealth & \\
Informed trader & 500,000 yuan \\
Technical trader & 500,000 yuan \\
Noise trader & 500,000 yuan \\
Arbitrage trader & $2,000,000$ yuan \\
Total number of experimental periods & 60,522 \\
Time span of each period & $5 \mathrm{~s}$ \\
Number of days of the experiment & 21 days (1 month) \\
Number of periods in each day & 2882 \\
\hline
\end{tabular}

${ }^{a}$ Although the arbitrage investor's wealth is set to four times that of the other investors, it is later shown that its capital occupation is 6.5 times that of the other investors 
Next, we analyze the effectiveness, risk, capital occupancy, and impact cost of trading strategies in detail.

\section{Effectiveness analysis}

Analyzing the effectiveness of trading strategies aims to determine whether the strategy can bring benefits to investors. In this study, we obtained 60,522 period data regarding all types of investors' wealth and divided them into 21 parts; each part contains 2882 period data, representing 1 day. Then, we calculated the daily wealth growth rate for all of them; Fig. 5 and Table 2 show the results.

Arbitrage is theoretically risk free, but risks still exist in actual transactions. For example, the index tracks risks. We purchase the index by buying a spot portfolio; this process will have index-tracking bias. For another example, the market affects risk. When investors purchase a large number of assets, they generally cannot deal in fixed prices. Therefore, arbitrage investors are likely to have negative returns. This is also in line with the real market.

ANOVA was used to better observe the differences between the wealth growth rates of the four types of investors. Table 3 shows the experimental results. ${ }^{6}$ The results indicate that although some groups' results are not significant, the last group is significant. This means the wealth growth rate differs among the four types of investors, and the effectiveness of the four trading strategies is therefore different. Specifically, the informed investment strategy is optimal; it is the only one that can increase the investor's wealth. The second is the technical trading strategy, which ultimately does not increase investor wealth; it did, however, offer opportunities for profit in the simulation experiment. The third is the arbitrage trading strategy; its average wealth growth rate is negative, but it offers a chance for profit through arbitrage. The last is the noise trading strategy. Noise traders suffered huge losses in the experiment, indicating that investors who are not informed and do not study do not successfully invest.

\section{Risk analysis}

When evaluating trading strategies for stock index futures, we should consider not only profitability but also risk to seek a balance between the two. Then, we analyze the wealth growth rate volatility of the four kinds of investors to evaluate the risk level of each trading strategy. Volatility is measured by standard deviation. We calculated the standard deviations of all types of investors' wealth growth rates to measure wealth growth rate volatility. Figure 6 and Table 2 show the results.

ANOVA was used to better observe the differences in wealth growth rate volatility. Table 3 shows the detailed values. We can see that there are significant differences between the wealth growth standard deviations of the four types of investors; the risks of all types of trading strategies show great differences. The average standard deviation of technical traders' wealth growth rate is the highest and is significantly higher than that of other investors. The technical trading strategy faces the biggest risks. The average standard deviations of the wealth growth rates of informed traders and arbitrage traders are similar. Accordingly, the risks of those strategies are similar, although the risk of

\footnotetext{
${ }^{6}$ The purpose of this study is to compare and analyze investment strategies in the stock index futures market. Therefore, investment strategies for the spot market are not covered in Table 3.
} 


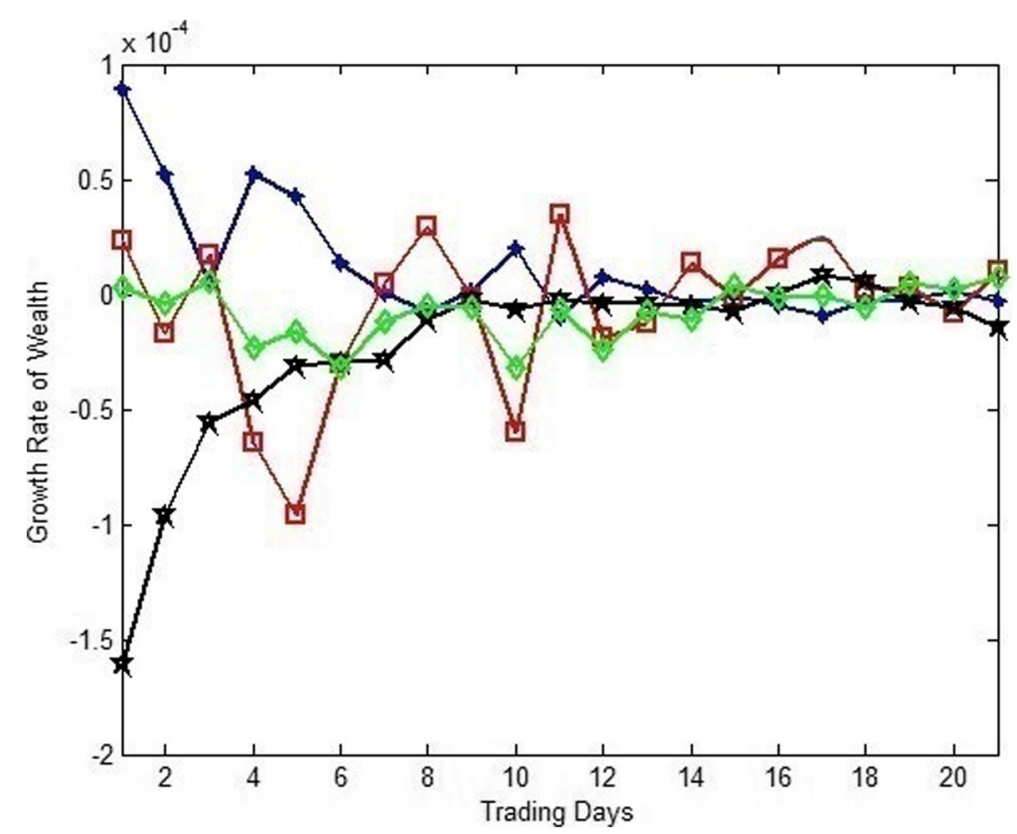

Fig. 5 Wealth growth rate of investors. Blue line: informed traders; Red line: technical traders; Black line: noise traders; Green line: arbitrage traders

the arbitrage trading strategy is slightly higher. Finally, the average standard deviation of the noise traders' wealth growth rate is minimal.

\section{Occupation of capital analysis}

In addition to the profitability and risk analysis, cost is also an important factor used to evaluate trading strategies for stock index futures. Cost can directly affect the effectiveness of trading strategies and the results of the execution. The cost of the trading strategy includes the occupation of capital and impact cost.

Occupation of capital refers to the capital investors need to pay for the transaction in unit order. A high degree of occupied capital means the trading strategy has greater risk. Informed traders, technical traders, and noise traders only invest in the stock index futures market while arbitrage traders invest in both. Thus, the

Table 2 Descriptive statistics for wealth growth rates and wealth growth rate volatility

\begin{tabular}{|c|c|c|c|c|}
\hline & Minimal & Maximum & Mean & Standard deviation \\
\hline \multicolumn{5}{|c|}{ Descriptive statistics for wealth growth rates } \\
\hline Informed trader & $-1.00 \mathrm{E}-05$ & $8.88 \mathrm{E}-05$ & $1.15 \mathrm{E}-05$ & $2.58 \mathrm{E}-05$ \\
\hline Technical trader & $-9.64 \mathrm{E}-05$ & $3.46 \mathrm{E}-05$ & $-6.28 \mathrm{E}-06$ & $3.32 \mathrm{E}-05$ \\
\hline Noise trader & $-1.61 \mathrm{E}-04$ & $8.15 \mathrm{E}-06$ & $-2.38 \mathrm{E}-05$ & $3.98 \mathrm{E}-05$ \\
\hline Arbitrage trader & $-3.18 \mathrm{E}-05$ & 7.29E-06 & $-7.60 \mathrm{E}-06$ & $1.19 \mathrm{E}-05$ \\
\hline \multicolumn{5}{|c|}{ Descriptive statistics for wealth growth rate volatility } \\
\hline Informed trader & $2.04 \mathrm{E}-04$ & $1.18 \mathrm{E}-03$ & $5.23 \mathrm{E}-04$ & $2.54 \mathrm{E}-04$ \\
\hline Technical trader & $6.08 \mathrm{E}-04$ & $2.50 \mathrm{E}-03$ & $1.56 \mathrm{E}-03$ & 5.77E-04 \\
\hline Noise trader & $2.22 \mathrm{E}-04$ & $5.74 \mathrm{E}-04$ & $3.91 \mathrm{E}-04$ & $1.06 \mathrm{E}-04$ \\
\hline Arbitrage trader & $2.38 \mathrm{E}-04$ & $1.03 \mathrm{E}-03$ & $6.02 \mathrm{E}-04$ & $2.31 \mathrm{E}-04$ \\
\hline
\end{tabular}


Table 3 ANOVA of wealth growth rates and wealth growth rate volatility

\begin{tabular}{|c|c|c|c|c|c|c|}
\hline Types & $\begin{array}{l}\text { Source of } \\
\text { variation }\end{array}$ & $\begin{array}{l}\text { Sum of squares } \\
\text { of deviations }\end{array}$ & $\begin{array}{l}\text { Degree of } \\
\text { freedom }\end{array}$ & $\begin{array}{l}\text { Mean } \\
\text { square } \\
\text { error }\end{array}$ & $\begin{array}{l}\mathrm{F} \\
\text { value }\end{array}$ & $P$ value \\
\hline \multicolumn{7}{|c|}{ ANOVA of wealth growth rates } \\
\hline \multirow[t]{3}{*}{$\begin{array}{l}\text { Informed trader-Technical } \\
\text { trader }\end{array}$} & $\begin{array}{l}\text { Difference } \\
\text { between groups }\end{array}$ & 2.89E-09 & 1 & 2.89E-09 & 3.21 & $0.081^{*}$ \\
\hline & $\begin{array}{l}\text { Difference in the } \\
\text { group }\end{array}$ & $3.60 \mathrm{E}-08$ & 40 & $8.99 \mathrm{E}-10$ & & \\
\hline & $\begin{array}{l}\text { Total square } \\
\text { deviation }\end{array}$ & $3.88 \mathrm{E}-08$ & 41 & & & \\
\hline \multirow[t]{3}{*}{$\begin{array}{l}\text { Technical trader-Noise } \\
\text { trader }\end{array}$} & $\begin{array}{l}\text { Difference } \\
\text { between groups }\end{array}$ & $3.72 \mathrm{E}-09$ & 1 & $3.72 \mathrm{E}-09$ & 2.74 & 0.106 \\
\hline & $\begin{array}{l}\text { Difference in the } \\
\text { group }\end{array}$ & $5.43 \mathrm{E}-08$ & 40 & 1.36E-09 & & \\
\hline & $\begin{array}{l}\text { Total square } \\
\text { deviation }\end{array}$ & $5.80 \mathrm{E}-08$ & 41 & & & \\
\hline \multirow[t]{3}{*}{$\begin{array}{l}\text { Noise trader-Arbitrage } \\
\text { trader }\end{array}$} & $\begin{array}{l}\text { Difference } \\
\text { between groups }\end{array}$ & 2.80E-09 & 1 & 2.80E-09 & 3.25 & $0.079^{*}$ \\
\hline & $\begin{array}{l}\text { Difference in the } \\
\text { group }\end{array}$ & $3.45 \mathrm{E}-08$ & 40 & $8.62 \mathrm{E}-10$ & & \\
\hline & $\begin{array}{l}\text { Total square } \\
\text { deviation }\end{array}$ & $3.73 \mathrm{E}-08$ & 41 & & & \\
\hline \multirow[t]{3}{*}{$\begin{array}{l}\text { Between the four types of } \\
\text { trading strategies }\end{array}$} & $\begin{array}{l}\text { Difference } \\
\text { between groups }\end{array}$ & $1.32 \mathrm{E}-08$ & 3 & 4.41E-09 & 5.01 & $0.003^{* * *}$ \\
\hline & $\begin{array}{l}\text { Difference in the } \\
\text { group }\end{array}$ & 7.04E-08 & 80 & $8.80 \mathrm{E}-10$ & & \\
\hline & $\begin{array}{l}\text { Total square } \\
\text { deviation }\end{array}$ & 8.37E-08 & 83 & & & \\
\hline \multicolumn{7}{|c|}{ ANOVA of wealth growth rate volatility } \\
\hline \multirow[t]{3}{*}{$\begin{array}{l}\text { Informed trader-Technical } \\
\text { trader }\end{array}$} & $\begin{array}{l}\text { Difference } \\
\text { between groups }\end{array}$ & $1.13 \mathrm{E}-05$ & 1 & $1.13 \mathrm{E}-05$ & 56.69 & $\begin{array}{l}3.47 \mathrm{E}- \\
09^{* * *}\end{array}$ \\
\hline & $\begin{array}{l}\text { Difference in the } \\
\text { group }\end{array}$ & 7.95E-06 & 40 & $1.99 \mathrm{E}-07$ & & \\
\hline & $\begin{array}{l}\text { Total square } \\
\text { deviation }\end{array}$ & $1.92 \mathrm{E}-05$ & 41 & & & \\
\hline \multirow[t]{3}{*}{$\begin{array}{l}\text { Technical trader-Noise } \\
\text { trader }\end{array}$} & $\begin{array}{l}\text { Difference } \\
\text { between groups }\end{array}$ & $1.43 \mathrm{E}-05$ & 1 & $1.43 \mathrm{E}-05$ & 83.24 & $\begin{array}{l}2.54 \mathrm{E}- \\
11^{* * *}\end{array}$ \\
\hline & $\begin{array}{l}\text { Difference in the } \\
\text { group }\end{array}$ & $6.88 \mathrm{E}-06$ & 40 & $1.72 \mathrm{E}-07$ & & \\
\hline & $\begin{array}{l}\text { Total square } \\
\text { deviation }\end{array}$ & $2.12 \mathrm{E}-05$ & 41 & & & \\
\hline \multirow[t]{3}{*}{$\begin{array}{l}\text { Noise trader-Arbitrage } \\
\text { trader }\end{array}$} & $\begin{array}{l}\text { Difference } \\
\text { between groups }\end{array}$ & 4.66E-07 & 1 & 4.66E-07 & 14.43 & $\begin{array}{l}5.00 \mathrm{E}- \\
04^{* * *}\end{array}$ \\
\hline & $\begin{array}{l}\text { Difference in the } \\
\text { group }\end{array}$ & $1.29 \mathrm{E}-06$ & 40 & 3.22E-08 & & \\
\hline & $\begin{array}{l}\text { Total square } \\
\text { deviation }\end{array}$ & $1.76 \mathrm{E}-06$ & 41 & & & \\
\hline \multirow[t]{3}{*}{$\begin{array}{l}\text { Between the four types of } \\
\text { trading strategies }\end{array}$} & $\begin{array}{l}\text { Difference } \\
\text { between groups }\end{array}$ & $1.80 \mathrm{E}-05$ & 3 & 5.99E-06 & 51.85 & $0.0000^{* * *}$ \\
\hline & $\begin{array}{l}\text { Difference in the } \\
\text { group }\end{array}$ & $9.24 \mathrm{E}-06$ & 80 & 1.15E-07 & & \\
\hline & $\begin{array}{l}\text { Total square } \\
\text { deviation }\end{array}$ & $2.72 \mathrm{E}-05$ & 83 & & & \\
\hline
\end{tabular}

$*, * *$, and $* * *$ indicate significance at the $0.10,0.05$, and 0.01 levels, respectively 


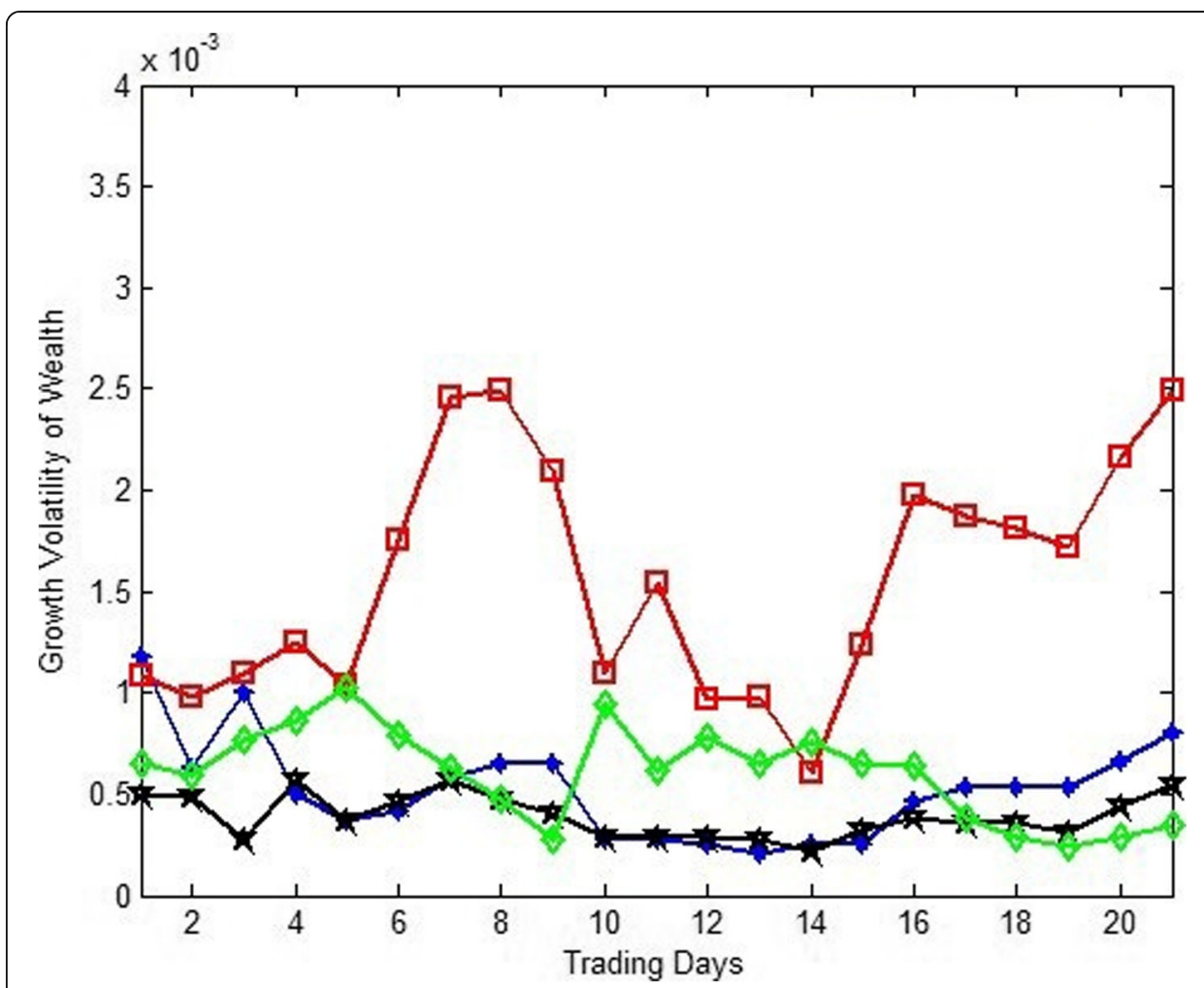

Fig. 6 Wealth growth volatility of investors. Blue line: informed traders; Red line: technical traders; Black line: noise traders; Green line: arbitrage traders

capital requirement of arbitrage traders is greater than that of the other three types.

We obtain 60,522 period data for the occupation of capital among all trading strategies. Then, we calculate the occupation of capital for each trading strategy in each day. Figure 7 and Table 4 show the experimental results.

Figure 7 shows that the occupation of capital for the arbitrage strategy is greater than that for the other strategies. The variance in the occupation of capital is also greater for the arbitrage strategy than for the others, meaning the arbitrage strategy is more volatile. As shown in Table 4, the average capital occupation of the arbitrage strategy is $3.43 \mathrm{E}+05$, and the average capital occupation of the other three strategies is $5.28 \mathrm{E}+04$. Thus, the capital occupation of arbitrage traders is nearly 6.5 times that of other investors, which means arbitrage traders do indeed need more capital.

\section{Impact cost analysis}

Trading strategies can affect market trends, which might in turn affect the execution of trading strategies and transactions at optimal prices. The loss caused by this situation is known as the market impact cost, which is another type of cost. This study uses the number of deals in the optimal price to measure the impact costs of the trading strategies. ${ }^{7}$ The larger the number of deals, the smaller the impact cost.

${ }^{7}$ The optimal price is the price in the first level of the buy (or sell) side order book. In the order books market, if the trading strategy deals more frequently at the optimal price level, then the market impact cost is small, and the trading strategy is executed smoothly (and vice versa). 


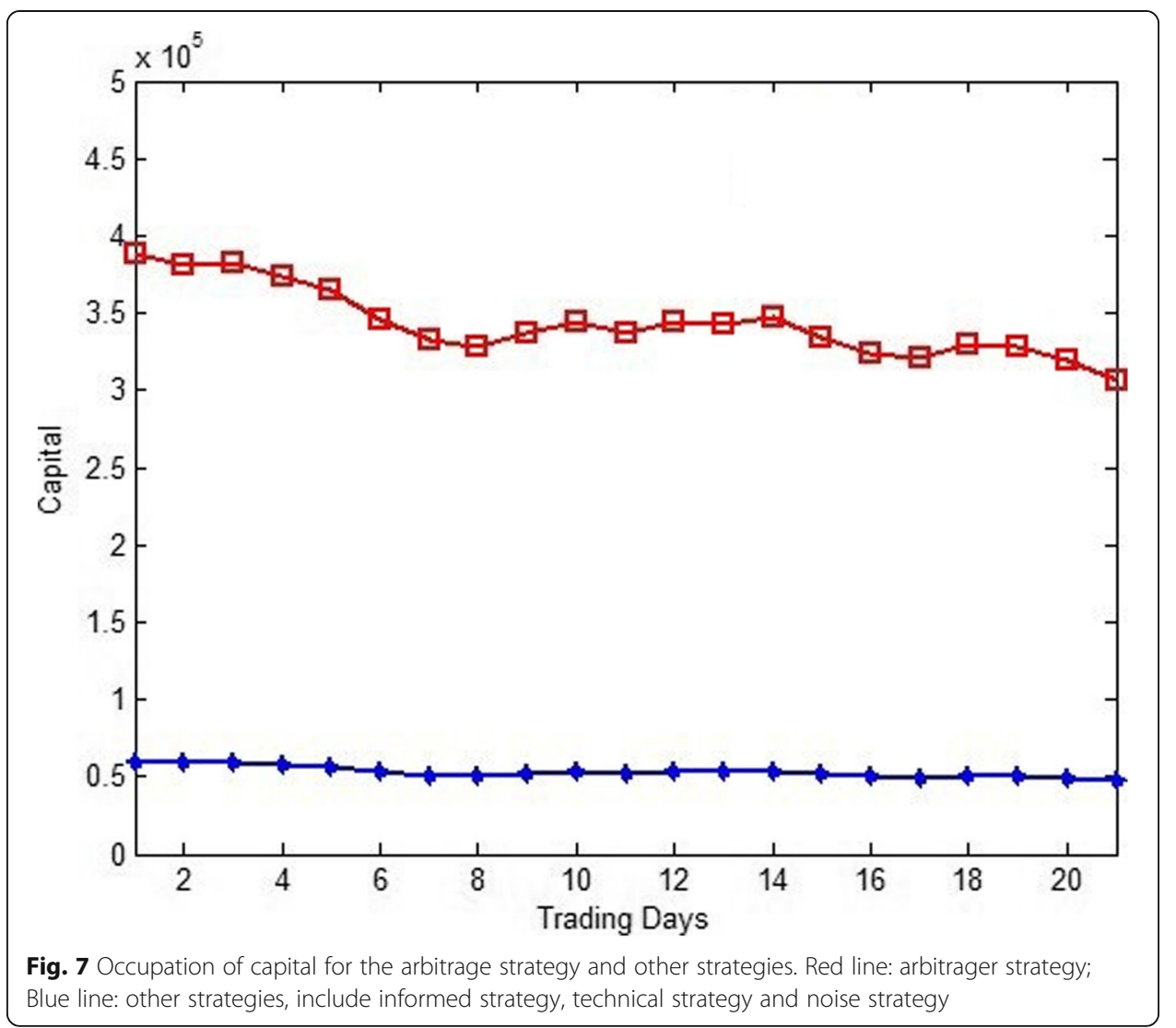

The informed, technical, and noise trading strategies are only used in the stock index futures market; they only affect that market and thus suffer impact costs from only one market. Meanwhile, since the arbitrage trading strategy operates in both markets simultaneously, it suffers impact costs from two markets. Thus, the impact cost of the arbitrage trading strategy is greater than that of the other three types.

We obtain high-frequency data for the number of deals at the optimal price in the stock market and the stock index futures market. We calculate the average value of the number of deals at the optimal price for the trading strategies to measure the daily average impact costs. Figure 8 and Table 4 show the experimental results.

We can see in Fig. 8 and Table 4 that the number of transactions at the optimal price in the arbitrage trading strategy is less than that of the other three strategies. This means the impact cost of the arbitrage trading strategy is higher than that of the others.

Table 4 Descriptive statistics for the occupation of capital and impact costs

\begin{tabular}{|c|c|c|c|c|}
\hline & Minimal & Maximum & Mean & Standard deviation \\
\hline \multicolumn{5}{|c|}{ Descriptive statistics for the occupation of capital } \\
\hline Arbitrage strategy & $3.07 \mathrm{E}+05$ & $3.88 \mathrm{E}+05$ & $3.43 E+05$ & $2.24 \mathrm{E}+04$ \\
\hline Other three strategies & $4.72 \mathrm{E}+04$ & $5.97 \mathrm{E}+04$ & $5.28 \mathrm{E}+04$ & $3.44 E+03$ \\
\hline \multicolumn{5}{|c|}{ Descriptive statistics for the impact costs } \\
\hline Arbitrage strategy & $6.90 \mathrm{E}-04$ & $1.52 \mathrm{E}-01$ & $6.91 \mathrm{E}-02$ & 4.62E-02 \\
\hline Other three strategies & $6.90 \mathrm{E}-04$ & 1.63E-01 & 7.41E-02 & 4.93E-02 \\
\hline
\end{tabular}




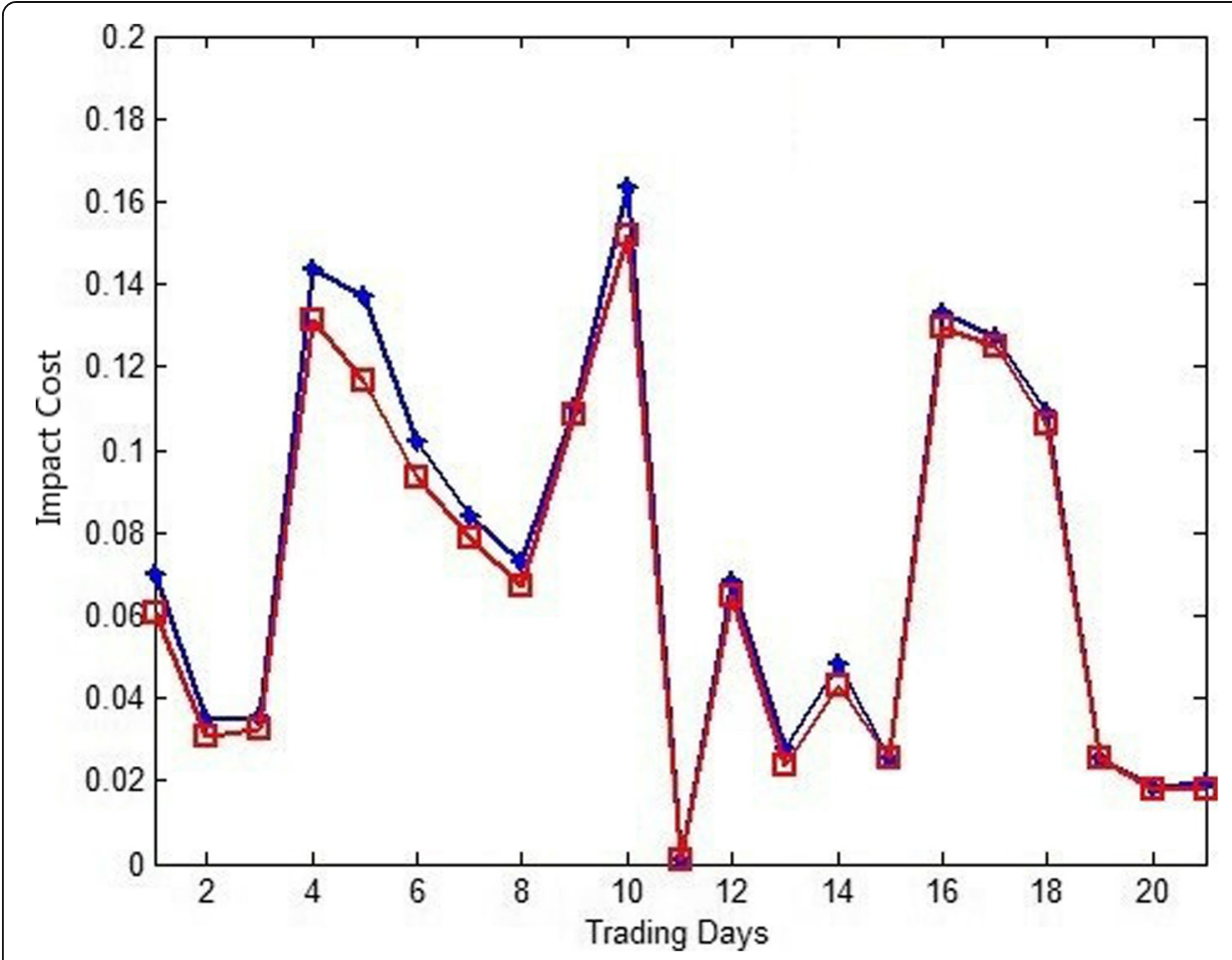

Fig. 8 Average impact costs of the arbitrage strategy and the other strategies. Red line: arbitrager strategy; Blue line: other strategies, include informed strategy, technical strategy and noise strategy

\section{Conclusion and discussion}

Evaluating trading strategies for the stock index futures market mainly involves analyzing benefits, costs, and risks. Cost analysis includes occupation-of-capital analysis and impact cost analysis. Each aspect (i.e., benefit, cost, and risk) can affect the profitability of a trading strategy. The effectiveness of the trading strategy is the basic indicator. If investors only pursue high returns and pay no attention to risk, occupation of capital, and the impact cost, they are likely to face huge risks and higher costs. Meanwhile, a lack of risk-management awareness and skills can affect market stability and cause sharp movements.

According to this study's analysis results, the informed trading strategy performs well in terms of effectiveness, risk, occupation of capital, and impact cost, indicating that the analysis of market information is very important. The noise trading strategy suffers heavy losses. The technical trading strategy performs well with regard to effectiveness, occupation of capital, and impact cost but has a relatively larger risk. If investors have better risk-management capabilities, their risks and benefits will be balanced at a higher level. Although the returns and risks of the arbitrage trading strategy are reasonable, it requires a lot of money. Further, because of the larger capital occupation and impact costs, investors using this strategy must focus on market changes.

This study has some limitations that can be improved upon in future work. First, the experiment could be done several times by changing the parameter settings (number of traders, initial wealth of traders, transaction costs, and so on) to observe the differences. This will help improve our understanding of trading strategies. Second, based on the main contract period of the China stock index futures market, the sample period was 
set to 1 month, and the basic unit of the research was set to 1 day. To observe different results and improve the evaluation system for stock index futures, both the sample period and the unit of time can be changed. Third, this study mainly uses the average value of market data as the basis for analysis. Future work can enrich the functions of the simulated market and observe changes in individual investor. This could provide a more accurate basis for evaluating trading strategies. Fourth, in the future, calibration studies of this model can be conducted to verify the connection and difference between the model and the real market.

This study has some practical implications. Namely, investors should continue to research and analyze the market to obtain sufficient market information. At the same time, they should continuously enrich their investment knowledge and skills, consider their situation in relation to market changes, update their trading strategies, and seek a balance between return and risk.

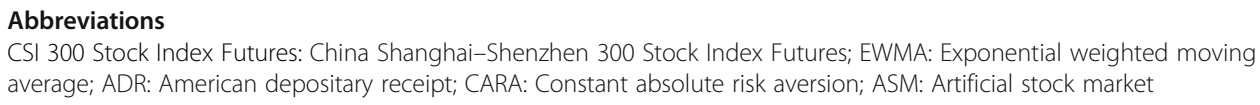

We thank the anonymous reviewers. Their comments and suggestions have greatly improved our paper.

Authors' contributions

This version is an anonymous review version. The author(s) read and approved the final manuscript.

\section{Funding}

The work was supported by the National Nature Science Foundation of China $(71532009,71320107003,71271145)$, Core Projects in Tianjin Education Bureaus Social Science Program (2014ZD13), Tianjin Development Program for Innovation and Entrepreneurship.

Availability of data and materials

All the data observations used in this paper come from the simulation data generated by the agent-based model in this paper.

\section{Competing interests}

The authors declare that they have no competing interests.

\section{Author details}

${ }^{1}$ College of Management and Economics, Tianjin University, Tianjin 300072, China. ${ }^{2}$ Research Institute, Shenzhen Stock Exchange, Shenzhen 518038, China. ${ }^{3}$ Jack H. Brown College of Business and Public Administration, California State University, San Bernardino 92407, USA.

Received: 7 January 2019 Accepted: 7 August 2020

Published online: 05 October 2020

\section{References}

Antoniou A, Koutmos G, Pericli A (2005) Index futures and positive feedback trading: evidence from major stock exchanges. J Empir Financ 12(2):219-238

Arthur WB, Holland JH, LeBaron B et al (1996) Asset pricing under endogenous expectations in an artificial stock market. The economy as an evolving complex system II 1996;27.

Battiston S, Farmer JD, Flache A (2016) Complexity theory and financial regulation. Science 351(6275):818-819

Bohl MT, Salm CA, Schuppli M (2011) Price discovery and investor structure in stock index futures. J Futur Mark 31(3):282-306

Brooks C, Rew AG, Ritson S (2001) A trading strategy based on the lead-lag relationship between the spot index and futures contract for the FTSE 100. Int J Forecast 17(1):31-44

Chang EC, Cheng JW, Pinegar JM (1999) Does futures trading increase stock market volatility? The case of the Nikkei stock index futures markets. J Bank Financ 23(5):727-753

Chen SH, Liao CC (2005) Agent-based computational modeling of the stock price-volume relation. Inf Sci 170(1):75-100

Chen SH, Venkatachalam R (2017) Agent-based modelling as a foundation for big data. J Econ Methodol 24(1):1-22

Chen Y, Yuan JH, Li XD, Xiao BQ (2010) Research on liquidity of Chinese futures markets via MCMC method. J Manag Sci China 13(9):119-128

Chiarella C, lori G, Perelló J (2009) The impact of heterogeneous trading rules on the limit order book and order flows. J Econ Dyn Control 33(3):525-539

Cui YA, Xiong X, Wei LJ et al (2020) Agent-based modelling from the perspectives of Fintech. Syst Eng Theory Pract 40(2): $373-381$ 
Hua RH, Liu QF (2010) The research on price discovery ability between stock index futures market and stock index spot market. J Quant Tech Econ 10:90-100

Iori G, Porter J (2018) Agent-based modeling for financial markets. In: The Oxford handbook of computational economics and finance

Jacob Leal S, Napoletano M, Roventini A et al (2016) Rock around the clock: an agent-based model of low-and highfrequency trading. J Evol Econ 26(1):49-76

Kobayashi S, Hashimoto T (2007) Analysis of circuit breakers using artificial stock market. In: Proceedings of the 12th international symposium on artificial life and robotics (AROB07), pp 260-263

Laws J, Thompson J (2005) Hedging effectiveness of stock index futures. Eur J Oper Res 163(1):177-191

Lee HT, Tsang WL (2011) Cross hedging single stock with American depositary receipt and stock index futures. Financ Res Lett 8(3):146-157

Li YL, Zhang W, Xiong X (2012) Impact of tick size on market liquidity by agent-based modeling approach. J Manag Sci 25(1): 92-98

Lussange J, Belianin A, Bourgeoisgironde S, et al. (2018) A bright future for financial agent-based models. Working Papers

Sarkar SK, Tripathy N (2002) An empirical analysis of the impact of stock index futures trading on securities dealers' inventory risk in the NASDAQ market. Rev Financ Econ 11(1):1-17

Schmitt N, Westerhoff F (2014) Speculative behavior and the dynamics of interacting stock markets. J Econ Dyn Control 45 262-288

Tesfatsion L (2006) Agent-based computational economics: a constructive approach to economic theory. In: Handbook of computational economics, vol 2, pp 831-880

Tong MH (2011) Shanghai Shenzhen 300 stock index futures dynamic hedge ratios model estimation and its comparison. $J$ Quant Tech Econ 28(4):137-149

Wei L, Zhang W, Xiong X, Zhao Y (2014) A multi-agent system for policy design of tick size in stock index futures markets. Syst Res Behav Sci 31(4):512-526

Wu S, Li XD, Zhang B (2013) Impacts of short sale on stock market based on computational experiment. J Manag Sci 26(4): $70-78$

Xiong X, Liang J, Cui Y, Zhang W, Zhang Y (2017) Analysis of the spot market's T+1 trading system effects on the stock index futures market. Eurasia J Math Sci Technol Educ 13(12):7679-7693

Xu HC, Zhang W, Xiong X, Zhou WX (2014) An agent-based computational model for China's stock market and stock index futures market. Math Probl Eng 2014:563912

Yang Y, Wan DF (2011) Can the stock index futures stabilize the market? J Financ Res 12:146-158

Zhao R, Cui Y, Liu X (2020) Tick size and market quality using an agent-based multiple-order-book model. Front Phys 8:135

\section{Publisher's Note}

Springer Nature remains neutral with regard to jurisdictional claims in published maps and institutional affiliations.

\section{Submit your manuscript to a SpringerOpen ${ }^{\circ}$ journal and benefit from:}

- Convenient online submission

- Rigorous peer review

Open access: articles freely available online

High visibility within the field

- Retaining the copyright to your article

Submit your next manuscript at $\boldsymbol{\nabla}$ springeropen.com 